\title{
Relevant Content for a Scientific Collaboration in Mathematics and Physics Education Research - A Comparative Content Analysis of Handbooks and Conference Proceedings in Germany and Vietnam
}

\author{
Eduard Krause ${ }^{1 *}$, Frederik Dilling ${ }^{1}$, Simon Friedrich Kraus ${ }^{1}$, Nguyen Phuong Chi ${ }^{2}$, \\ Tran Ngoc Chat ${ }^{2}$, Nguyen Van Bien ${ }^{2}$ \\ 1 University of Siegen, GERMANY \\ ${ }^{2}$ Hanoi National University of Education, VIET NAM
}

Received 19 September 2019 • Revised 7 November 2019 • Accepted 7 November 2019

\begin{abstract}
This article presents a possible framework for the cooperation of mathematics and physics education research domains. Moreover, the potential topics for such a scientific collaboration are explained by means of a structuring qualitative content analysis of current handbooks and conference proceedings in Germany and Vietnam. These topics can form a basis for further projects on the connection of subject-related didactics. One of these projects is an interdisciplinary course in teacher training at the Hanoi National University of Education (HNUE) as part of the Inter TeTra project between the HNUE and the University of Siegen.
\end{abstract}

Keywords: interdisciplinarity, international comparative study, qualitative content analysis, relationship between mathematics and physics, STEM education, teacher training

\section{INTRODUCTION}

Mathematics and physics educators from the University of Siegen and the Hanoi National University of Education are collaborating within the Inter TeTra project. The objective of this project is the systematical combination, application and reflection of the involved disciplines (Kraus et al., 2018; Krause et al., 2019). An essential intermediate goal of this cooperation is the identification of content intersections between the involved didactics. The results of this analysis are presented in this article.

The second section shows a literature review on interdisciplinary collaboration of education researchers in this field. It describes why the cooperation of German and Vietnamese educators as well as mathematics and physics educators is particularly suitable. The research questions are presented in the third section and the fourth section describes the research process and methodology. The research result is described in section "Results of the study". Section "Explication of possible topics for a science collaboration of mathematics and physics didactics" deals with the interpretation of the results by a short description of the respective comparison points of both disciplines.

(C) 2020 by the authors; licensee Modestum Ltd., UK. This article is an open access article distributed under the terms and conditions of the Creative Commons Attribution License (http://creativecommons.org/licenses/by/4.0/). $\triangle$ krause@mathematik.uni-siegen.de (*Correspondence) $\square$ dilling@mathematik.uni-siegen.de 


\section{Contribution of this paper to the literature}

- A structured comparison of conference contributions and common handbooks of mathematics and physics education research allows us to identify possible common research topics.

- On the basis of a survey of experts, a selection is made of such topics that have a special potential for deeper discussion in an interdisciplinary course in the teacher training program, in which the participants learn to recognize and use the synergies of both subjects for a contemporary interdisciplinary teaching.

- We carry out a comparison between countries that have made varying degrees of progress in implementing competence-oriented teaching; current trends in research in the participating countries are compared.

\section{ABOUT THE POTENTIAL OF INTERDISCIPLINARY COLLABORATION OF EDUCATION RESEARCHERS}

\section{Collaboration of German and Vietnamese Teacher Educators in the Context of the Educational Reforms in Vietnam}

In international comparative studies, Vietnam usually achieves very satisfactory results (in the last PISA study, Vietnam achieved better rankings in the disciplines Mathematics and Science than, for example, the USA and the UK), but the educational provision still shows weaknesses in particular in the tertiary sector (Tran, 2018a). In 2006, Vietnam adopted an agenda for higher education reform that promised significant improvements in higher education by 2020 (Hayden \& Thiep, 2006). The education system was to evolve from a more Soviet to a Western style (Whitney et al., 2018). Therefore, the globalization of higher education is one of the fundamental initiatives (Tran, 2018b).

In the area of teacher training, the reforms are primarily aimed at establishing competence-oriented curricula (Communist Party, 2013). This means that teachers are asked to design lessons in such a way that students can apply the acquired skills and abilities in various situations in a problem-solving manner. Therefore, interdisciplinarity is a logical consequence of the demand for competence-oriented teaching and learning, since authentic contextualization of learning content usually goes beyond the boundaries of subjects. Germany has two decades of experiences with these types of reforms. The adjustments of the curricula since the mediocre results of German students in the TIMSS and PISA studies show the opportunities and challenges such reforms can present (KMK, 2004) and the importance of teacher training for the success of school reforms (Hattie \& Beywl, 2013). Therefore, the cooperation between German and Vietnamese educators offers the opportunity to avoid well-known problems in implementing such reforms.

\section{Teaching and Learning in STEM - With a Focus on Mathematics and Physics}

Competence-oriented Mathematics education should enable students to understand phenomena in nature and society (Sevinc \& Lesh, 2018). Similarly, the description of phenomena of reality is a central goal of physics education. However, these phenomena are not divided into single subjects. Of course, it makes sense to structure knowledge in subjects and to adopt problems with subject-specific methods for many purposes. Nevertheless, interdisciplinary approaches can provide meaningful insights - especially in STEM. Since the establishment of competence orientation, the didactic potential of interdisciplinary teaching and learning in schools has actually been emphasized more strongly. Different approaches have been developed (Doig et al., 2019). In addition, interdisciplinary activities replace the divided teaching of subjects (e.g. Project-based learning). It seems useful to teach the single subjects in an interdisciplinary way by establishing links to related subjects. For example, mathematics is related to numerous applications of STEM-subjects (science, technology, engineering, mathematics) (Trần \& Kraus, 2017), but also to the social sciences (politics, geography, etc.) (Trân, 2013) and the artistic field (sports, music, art etc.). Such applications can be integrated into the mathematics lessons in a meaningful way (Trần \& Krause, 2017). The potential of interdisciplinary teaching and learning has been discussed extensively in the context of STEM-education (English, 2017; Kelley \& Knowles, 2016; La Force, 2016; Michelsen, 1998). Regardless of the increasing demands of interdisciplinary teaching within the subjects, science, technology, engineering, and mathematics (STEM), there is no agreement on a definition of STEM (Baker \& Galanti, 2017; Fullan, 2007). According to some authors, STEM can already be considered if only two disciplines from this field are integrated (Ríordáin, Johnston, \& Walshe, 2016; Treacy \& O'Donoghue, 2014). The cooperation between mathematics and physics didactics seems to be particularly useful, because mathematics and physics also exhibit numerous synergies as academic disciplines. In the historical genesis, mathematics and physics have been beneficial in many ways (Galili, 2018; Krause, 2018). In fact, mathematics didactics has a high relevance in the research of teaching and learning processes in physics (Krause, 2017b). For example, the high presence of mathematical notations and 
techniques in quantitative physics makes mathematics didactic aspects on dealing with formulas very interesting for physics didactics.

In mathematics lessons, physics is very present, too. It provides authentic contexts in many areas of school mathematics. Students in mathematics lessons should learn how mathematics can be used to perceive and understand natural phenomena (see e. g. Carrejo \& Marshall, 2007). However, mathematics teachers are often overwhelmed with physical contexts because they lack both the contentual and the subject-specific didactic knowledge (Krause, 2017a).

\section{The Inter TeTra Project as an Interdisciplinarity Intervention in University Teacher Training}

In Vietnam, educational researchers currently work on approaches for establishing interdisciplinary lessons in Vietnam (Nguyen \& Thanh, 2014 or Nguyen, 2015). Studies in Vietnam show that interdisciplinary teaching is aimed to motivate students, put them in authentic activities, develop their integrated skills and their competencies to solve real-world problems (Đỗ et al., 2016; Nguyen, 2016). Processes of designing and organizing interdisciplinary teaching are also studied (Đỗ et al., 2016; Nguyen et al., 2018, 2019). The new Vietnamese General Curriculum, adopted in 2018, contains a new change in the lower secondary level: the three subjects, Physics, Chemistry, and Biology are integrated into a new subject named "Natural Science". Together with this integration, the curriculum emphasizes that the goal of the new subject "Natural Science" is "to help students gradually form and develop their natural science competencies through observations and experiential learning, synthesize integrated knowledge and skills to solve problems in real life, and perform STEM education together with other subjects such as Mathematics, Technology, Informatics...". (MOET, 2018, p. 20). STEM education is also mentioned in the objectives of teaching mathematics: "Mathematics education establishes connections between mathematical ideas, between mathematics and real life, between mathematics and other school subjects and other educational activities, especially the connections between mathematics and the subjects Science, Natural Science, Physics, Chemistry, Biology, Technology and Informatics to perform STEM education" (MOET, 2018, p. 17).

Although recognizing the importance of interdisciplinary teaching, the Vietnam Ministry of Education and Training still have difficulties in performing it. The school curriculum was innovated but the pre-service teachers' curriculum still has not changed in the pedagogical universities. This contradiction leads to the problem that when pre-service teachers graduate and become teachers, they do not know how to integrate school subjects in the teaching process. The survey in the project "Teaching mathematics at the high school level in an integrated way through interdisciplinary projects" shows that high school mathematics teachers understand and are aware of the necessity of interdisciplinary teaching but they have difficulties in applying it, because of the limited teaching time, the lack of instructive documents, and the lack of the (pedagogical) content knowledge of other subjects (Nguyen \& Nguyen, 2019).

In Germany, the advantages of interdisciplinary teaching and learning in schools have been emphasized extensively in the form of problem-based and cross-disciplinary teaching which is organized in projects (Labudde, 2014 or Moegling, 2010). Numerous approaches have been developed in order to achieve the greatest success of learning (Caviola, 2012 or also Labudde, 2008). However, interdisciplinary collaborations also reveal different challenges. For instance, combination of different methods of the participating subjects and the identification of common research subjects are significant (Defila \& Di Giulio, 2002, 24). The contrast of a non-integrated teacher training and the requirements of interdisciplinary teaching (Bröll \& Friedrich, 2012) is repeatedly mentioned by teachers in German schools as an argument against interdisciplinary teaching (Jürgensen, 2012; Rehm et al., 2008). The importance of adequate preparation is also demonstrated in several studies (Brown \& Bogiages, 2017; Cormas, 2017). In order to prepare teachers adequately for this variety of challenges, we believe that early intervention is necessary in the first phase of teacher training. Nevertheless, the teacher training in Germany and Vietnam is predominantly still organized in a discipline-oriented manner. In contrast, the aim should be to implement holistic concepts for integrative teacher education. Thus, interdisciplinary teaching and learning in schools are more than stringing together elements of knowledge from different disciplines (Wellensiek, 2002, 80).

\section{RESEARCH QUESTIONS}

The potential synergies between mathematics and physics didactics formulated in Chapter 2 are systematically highlighted by means of a structuring analysis of handbooks for both subject-related didactics and of conference proceedings. The research questions are as follows:

1) Which of the educational research subject areas within mathematics and physics currently being discussed in Germany and Vietnam are relevant for both subjects? 


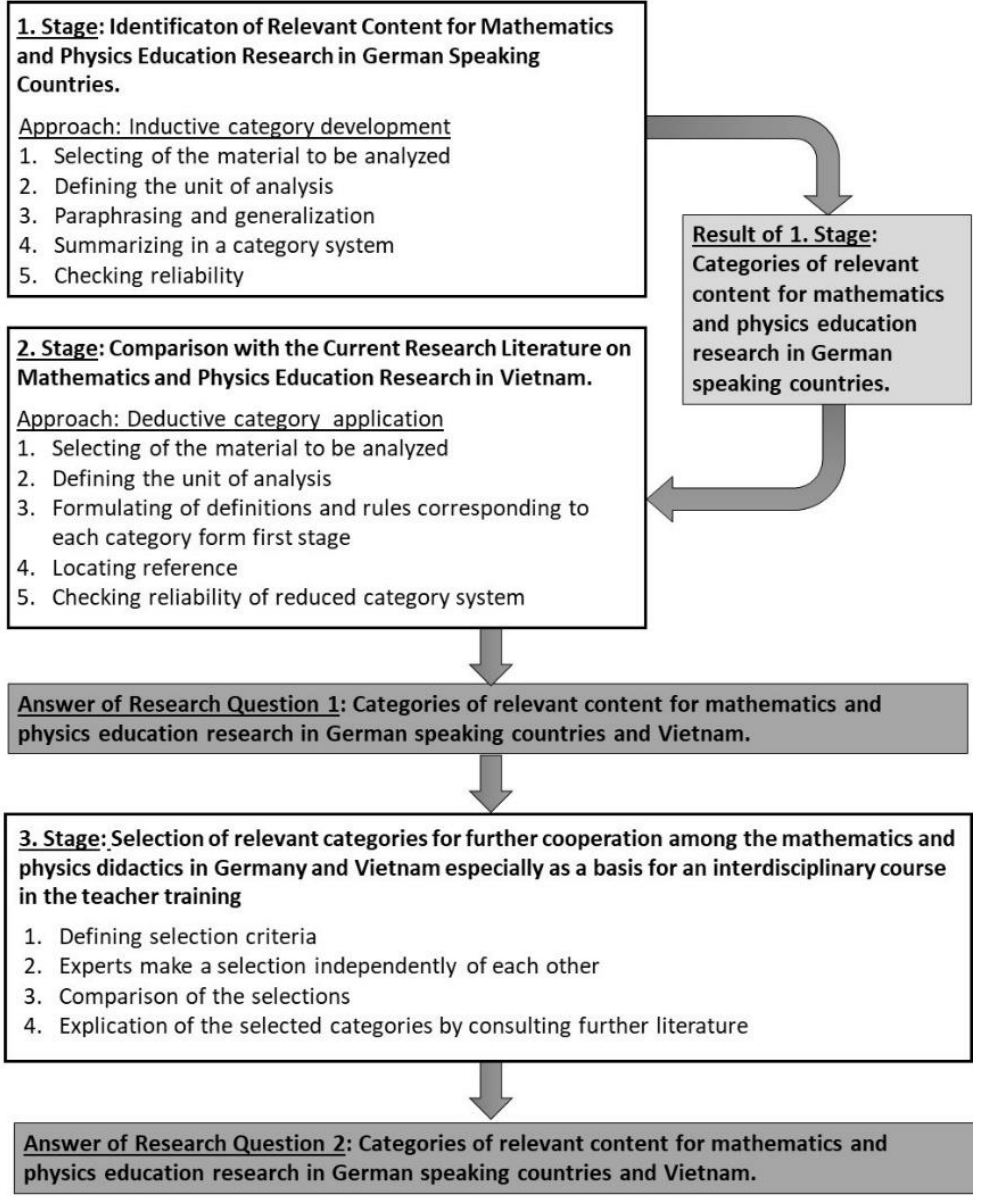

Figure 1. Graphical representation of the general research process sequence

2) Which of the contents found are particularly valuable as a basis for further cooperation among the mathematics and physics didactics in Germany and Vietnam especially as a basis for an interdisciplinary course in the teacher training?

\section{METHODOLOGY}

\section{Basis for Selecting Methods and Research Process}

In order to answer the first research question, the content needs to be qualitatively analyzed. The method chosen in this study is based on the theory of qualitative content analysis according to Mayring (2000). Qualitative content analysis is used in two different ways in this study - inductive development of categories as well as deductive application of categories.

Since so far no study has systematically identified common topics in mathematics and physics education research in German-speaking countries as well as in Vietnam, it is necessary first to use the approach of inductive category development. If the German and Vietnamese literature were analyzed parallel as inductive category development approach, we would have results of two independent categories. Since this is a qualitative analysis, the results depend subjectively on the researcher. Therefore, the structure of the system of categories can be very different and hard to compare. Hence, the research process is arranged in three successive stages. In the first stage, the contents are identified, which are relevant for both mathematics and physics education research in Germanspeaking countries. This analysis is carried out according to the inductive development of categories. In the second stage, the results of the first stage are compared with the current literature on mathematics and physics education research in Vietnam. The analysis in this stage is carried out according to the deductive application of categories (cf. Figure 1). As a result of these two stages, the first research question can be presented in the form of a list of categories relevant to the didactics of both subjects and countries. 
In the third stage of the research process, the second research question is answered. Therefore, criteria are defined for the selection of particularly relevant topics. Further literature was consulted to explicate the possible topics envisaged in the second research question. The content intersection identified in this way can form the basis for further cooperative research and teaching projects, such as the development of integrated teacher training at universities described above.

\section{Description of Methods}

Based on the first research question, the relevant literature is analyzed as inductive qualitative content in five steps. The result of this analysis are the German categories according to the approach: Inductive category development for qualitative content analysis from Mayring (2000). The first step is the selection of the handbooks and conference proceeding to be analyzed. The criterion for the literature selection is, the popularity of being used at German universities. In the second step, the material is described in detail, and the single units of analysis are defined. These are the contributions in the handbooks and conference proceedings. Therefore, the content of a single contribution forms the unit of analysis, which is examined for the relationship between the disciplines of mathematics and physics didactics. In the third step, the relevant parts of the text are summarized in a form limited to the content (paraphrasing). The paraphrases are generalized on a defined level of abstraction. The abstraction level is the topic of the contributions in the concrete case, whereas the generalization already followed from an interdisciplinary perspective (mathematics and physics didactics). In the fourth step, the statements are summarized in a system of categories. For this purpose, the inductively obtained subcategories are arranged by forming seven main categories. The category system was checked on the basis of the literature, in the last step of the analysis. These results of the German analysis have already been published (Dilling et al., 2019).

After creating the German categories, the relevant Vietnamese literature is analyzed according to the five-step deductive category application approach according to Mayring (2000) also taking into account the relationship between mathematics and physics. The first and the second step are done similar to the first two steps of the first research stage on the basis of the Vietnamese literature. The deductively developed system of categories based on the first research stage is presented in the third step and is applied to the Vietnamese literature in the fourth step by indicating definitions, coding rules and examples within the Vietnamese literature. This part of the result is presented in section "Explication of possible topics for a science collaboration of mathematics and physics didactics". In the last step, each category, which cannot be identified in the Vietnamese literature is excluded to form a new system of categories as a premise for research collaborating didactics of both subjects and countries, and to answer the first research question. To answer the second research question, each category with corresponding content is analyzed on the perspective of science collaboration and designing topics related to form the interdisciplinary course at the HNUE. For this purpose, a selection of particularly relevant contents for scientific cooperation in mathematics and physics didactics is independently made by proven experts in mathematics and physics didactics. These experts should make this selection independently of each other and according to the following qualification criteria:

Q1 Subject-specific relevance (topics that are analogously relevant in all subjects, e.g. the contribution to general education should not be discussed in the projected)

Q2 Relevance for the mathematics and physics teacher training program

The comparison of the selection of the respective experts led to the list of topics presented in "Selection of the Subject Specific Topics" as answers to the second research question.

\section{RESULTS OF THE STUDY}

\section{Handbooks and Conference Proceedings in Germany}

In order to reveal relevant subject areas for exchange between mathematics and physics didactics, the contents of nine basic mathematics and physics didactics handbooks as well as the contributions of the major conferences, the Gesellschaft für Didaktik der Mathematik (Society for Mathematics Education) and the Deutsche Physikalische Gesellschaft (German Physical Society), from 2014 to 2018, are compared. Contributions for conferences concerning other natural sciences (e.g. GDCP conference, MNU congress) are not included in the analysis in order to focus specifically on the connections between mathematics and physics education research. The analyzed conference proceedings represent an overview of the current research interests of mathematics and physics didactics. The inclusion of newer and older handbooks also makes it possible to take traditional research interests of the Germanspeaking research communities into account. Together, they form the analysis corpus of this study. The handbooks and proceedings, which are used for the analysis, are listed in Table 1. 
Table 1. Overview of the analyzed handbooks and conference proceedings from the German-speaking countries.

\begin{tabular}{|c|c|}
\hline Mathematics & Physics \\
\hline Handbooks & Handbooks \\
\hline Bruder et al. (2015) & Kircher et al. (2015) \\
\hline Krauthausen (2008) & Kircher et al. (2002) \\
\hline Leuders (2003) & Mikelskis (2006) \\
\hline Leuders (2015) & Wiesner et al. (2011) \\
\hline \multicolumn{2}{|l|}{ Reiss \& Hammer (2013) } \\
\hline \multicolumn{2}{|l|}{ Zech (2002) } \\
\hline Proceedings & Proceedings \\
\hline $\begin{array}{l}\text { Beiträge zum Mathematik unterricht } 2014-2017 \text { as well as the } \\
\text { program of presentations of the GDM } 2018 \text {. }\end{array}$ & $\begin{array}{l}\text { PhyDid B 2014-2017 and the program of presentations of the } \\
\text { DPG Conference for Physics Didactics } 2018 \text {. }\end{array}$ \\
\hline
\end{tabular}

Table 2. German categories

\begin{tabular}{ll}
\hline Number & Description \\
\hline C1 & Mathematics (didactics) and Physics (didactics) as scientific disciplines \\
\hline C1.1 & Relevance of mathematics/physics \\
\hline C1.2 & Mathematics/physics didactics as a scientific discipline \\
\hline C1.4 & Beliefs about mathematics/physics \\
\hline C2 & History of mathematics/physics (in class) \\
\hline C2.1 & Theories of didactics \\
\hline C2.2 & Didactic principles / theoretical principles of learning \\
\hline C2.3 & Students' ideas / pre-concepts / basic ideas / ... \\
\hline C3 & Subject Matter Didactics \\
\hline C3.1 & Objectives and competencies in mathematics and physics teaching \\
\hline C3.2 & Objectives and competencies \\
\hline C3.3 & Model / Modeling / Applications \\
\hline C3.4 & Pefinition/concept formation \\
\hline C3.5 & Arguing and proving \\
\hline C3.6 & Experimenting \\
\hline C3.7 & Communication / Language \\
\hline C4 & Teacher training \\
\hline C4.1 & Teacher training/professionalization of teachers/competencies of teachers \\
\hline C4.2 & Student laboratories / Teaching and learning laboratories \\
\hline C4.3 & Transition from school to university/commencement of studies \\
\hline C5 & Teaching practice and pedagogical topics \\
\hline C5.1 & Planning, analysis, and organization of lessons \\
\hline C5.2 & Teaching methods \\
\hline C5.3 & Performance assessment and diagnostics \\
\hline C5.4 & Media \\
\hline C6 5 & Differentiation / heterogeneity / inclusion \\
\hline C7 & Tasks \\
\hline
\end{tabular}

The analysis of the handbooks and conference proceedings results in a total of 24 categories representing related topics of mathematics and physics didactics. The developed categories can be grouped into seven main categories with partial splitting into several subcategories and ultimately enable the identification of 24 subject areas, that are comparable between the two didactics. A corresponding list of the categories is shown in Table 2. Additional anchor examples are given in Table 4 in the Appendix.

\section{Comparison with the Vietnamese Literature}

\section{Selection of literature}

There are two types of literature, which are selected for this analysis: handbooks and conference proceedings. The criterion for the selection of handbooks is their dissemination at Vietnamese universities of education. The criteria for selecting those conference proceedings are the proceedings from prestigious conferences in the field of 
Table 3. Overview of the analyzed handbooks and conference proceedings from Vietnam

\begin{tabular}{|c|c|}
\hline Mathematics & Physics \\
\hline$\underline{\text { Handbooks }}$ & $\underline{\text { Handbooks }}$ \\
\hline Nguyen(2017) & Đào (2003) \\
\hline Nguyen et. al (1994) & Đỗ (2006) \\
\hline Bui (2011) & Đỗ (2012) \\
\hline Bui (2017) & Đỗ (2014) \\
\hline \multirow[t]{2}{*}{ Dao \& Tran (2010) } & Đỗ et al. (2016) \\
\hline & Đỗ et al. (2019) \\
\hline Proceedings & Lê et al. (2004) \\
\hline The national conference of research on mathematics education & Nguyễn \&Nguyễn (2001) \\
\hline in the orientation of developing learners' competencies for the & Nguyễn et al. (2002) \\
\hline period 2014-2020 (2014). & Phạm (2001) \\
\hline The conference of developing professional competencies for & Phạm (2007) \\
\hline Vietnamese school mathematics teachers (2015). & Proceedings \\
\hline $\begin{array}{l}\text { The international conference in mathematics education: An } \\
\text { integrated approach in mathematics education and teacher } \\
\text { training (2018). }\end{array}$ & $\begin{array}{l}\text { Proceeding of Vietnam national conference for physics } \\
\text { teaching, from } 2010 \text { to } 2018\end{array}$ \\
\hline
\end{tabular}

mathematics and physics didactics from 2010 to present. Accordingly, the handbooks and proceedings listed in Table 3 are chosen for the analysis.

\section{The reduced category system}

For each German category analyzed in the previous stage, we choose which category is valid in the Vietnamese literature. From there on, the reduced category system is formed. In comparison with the Germany category system, there is no presence of the main categories C6 and C7. In addition, the categories C4.2 and C4.3 cannot be found parallel to their reference in both the mathematics and physics didactics in Vietnamese literature. The detail result is shown in Table 4 in the Appendix.

\section{Selection of the Subject Specific Topics}

The categories, which are obtained from the comparative analysis, represent exactly those subject areas, which are discussed in both subject didactics nowadays and are shaped by related contents. They describe both traditional (e.g. C1.1) and new (e.g. C3) knowledge interests of the two subject didactics. The categories differ in their didactic potential with regard to a comparison in the sense of a subject-didactic-connecting approach. i.e. regarding the integrated teacher training described at the beginning of an interdisciplinary scientific exchange with other objectives, the categories presented here have different relevance.

In order to filter out subject-specific topics that are particularly relevant for scientific cooperation from the list of discussed topics in mathematics and physics didactics in Germany and Vietnam, experts from both subjects and from both countries are asked to make an appropriate selection independently of each other. The comparison of this selection of experts led to the deletion of the following topics:

- C2.1 General didactic principals

- C2.3 Subject matter didactics

- C3.7 Communication and language

- C6 Tasks in class

Hence, the following seven topics have proved particularly promising for cooperation between mathematics and physics educational research:

- C1.3 Beliefs about mathematics and physics

- C2.2 Preconceptions

- C3.2 Models and Modeling

- C3.3 Concept formation

- C3.4 Problem-Solving

- C3.5 Arguing and Proofing

- C3.6 Experimentation 


\section{EXPLICATION OF POSSIBLE TOPICS FOR A SCIENCE COLLABORATION OF MATHEMATICS AND PHYSICS DIDACTICS}

\section{Beliefs about Mathematics and Physics}

Physics education in Germany (GP): The term Nature of Science (NoS for short) has long been used in physics didactics to describe the philosophical background of the natural sciences. The methodology of physics within the framework of theory-building processes is thereby explained as a central teaching subject. The experiment functions both as a medium and learning object in physics teaching and as a decisive explanatory instance and a link to reality in scientific methodology (Kircher, 2015). The ideas of students of NoS are also regularly discussed in the didactics of the subject (Höttecke \& Rieß, 2007).

Mathematics education in Germany (GM): In mathematics didactics, subject-specific views on mathematics are increasingly being investigated in open questionnaire studies (Rott et al., 2015). Grigutsch et al. (1998) were able to identify four factors in the attitude of mathematics teachers towards mathematics in a closed questionnaire format. 'This format still serves as the basis for studies (Witzke \& Spies, 2016). These are the formal aspects, in which mathematics is attributed rigor and exactness at different levels: the application aspect, which illuminates every day and social relevance, the process aspect, according to which mathematics is constructively understood as a process, and the schema aspect, which regards the algorithms and schemata of mathematics as tools.

Physics education in Vietnam (VP): NoS is also presented by Phạm (2007). In addition, Nguyễn \& Nguyễn (2001) illustrate NoS in the history of physics. Experimental methods and modelling methods are considered basic methods for natural awareness, and considered as subjects to be learned by students (Nguyen et al. 2002).

Mathematics education in Vietnam (VM): In mathematics education, beliefs about mathematic is mentioned by Nguyen (2017) through the properties of the subject mathematics: mathematics is highly abstract, popularly applicable, logical and experimental. According to Nguyen, the abstraction in mathematics is expressed in different ways. In other words, the highly abstract property makes mathematics be popularly applicable, that means mathematics can be applied in various fields and become a useful tool of these fields. Nguyen also emphasizes the logic and experimental properties of mathematics and concludes that the unification between deduction and prediction of mathematics is a property of mathematical thinking. We stress that both aspects of the teaching process be included to ensure the comprehensive goal of education (Nguyen, 2017).

A comparison of the research on the understanding of mathematics and physics didactics can provide deeper insights into the backgrounds and methods of one subject and the connection with the other. The scientific philosophy of the involved subjects has to be known to enable interdisciplinary learning.

\section{Preconceptions}

Ideas of different groups of persons concerning the contents of mathematics and physics are the more frequent subject of research in both didactics.

GP: In this context, physics didactics often speaks of everyday idea of physical phenomena that students should acquire outside the classroom. They are deeply rooted and often not compatible with scientific theory. This is the reason why the negatively connoted word "misconceptions" is often used in this context. The lessons should respond to the students' ideas and bring out a change of the concept. This can be done either by connecting and reinterpreting the ideas or by cognitive conflict and subsequent learning of the new concept (Duit, 2015).

GM: In mathematics didactics, students' ideas are examined in different contexts. According to vom Hofe (1992), basic ideas (Ger.: "Grundvorstellungen") can, in particular, be seen as a prescriptive description of ideas. On the basis of the mathematical content, possible ideas are developed which the teaching is intended to convey in this field. Examples in the field of analysis can be found in Greefrath et al. (2016). In contrast, there are many descriptive perspectives on the concept of imagination. These include, among others, the subjective fields of experience according to Bauersfeld (1983) as well as different approaches of the field of beliefs (e.g. Pehkonen \& Pietilä, 2004; Schoenfeld, 1998).

VP: Đỗ (2014) does not only present the psychological basis of preconception, but also makes suggestions to use preconception in teaching to have beneficial learning results. Furthermore, practical research on misconception is also explored by Hà (2016).

VM: In mathematics didactics, preconceptions are almost not mentioned. Only misconceptions are considered. Nguyen (2017) mentions "obstacles" as one kind of students' misconception. He differentiates "avoidable obstacles" and "unavoidable obstacles" and proposes methods to deal with each kind of obstacles in the teaching process (Nguyen, 2017). Other researcher focus on identifying common mistakes or misconceptions that students do by studying specific mathematical content such as quadratic equation (Ho, 2018) or 3D-geometry (Bui, 2011). 
Krause (2015) examines the comparison between mathematics and physics didactics and subjective learning preconditions in detail. The authors' impression is that cognitive-psychological aspects of subjective learning prerequisites have long been discussed in mathematics (Bauersfeld, 1983, among others). These are usually not specific for mathematics. Hence, these approaches could also be applied in physics didactics. Scientific exchange in this area seems very beneficial from the authors' point of view.

\section{Models and Modelling}

GP: Models are important components of the process of acquiring knowledge in physics and physics teaching. For this reason, physics didactics deals with the concept of models for a long time. Of particular importance is the relationship between model and object as well as the properties and functions of models (Kircher, 2015). The students should be actively integrated into the developmental process of models and modelling. Hence, the student should be aware of the fact that models are not regarded as something naturally given (Mikelskis-Seifert \& Kasper, 2011). Important for physics didactics are also considerations about what teachers should know about models (Oh \& Oh, 2016).

GM: In mathematical didactics, the interest is less in the model as an already finished product, but rather in the process of modelling. The model is supposed to be a link between mathematics and reality (Kaiser et al, 2015). In this course, different modelling cycles were developed, which represent models for the process of modeling. One of the best-known modelling cycles is the model by Blum and Leiß (2005).

VP: The analysis of the development of the concept of models in physics and the suggestions of the levels of modelling used in teaching are presented by Nguyễn and Nguyễn (2001). Nguyễn et al. (2002) detail the analysis of the characteristics of model types and introduce the concept of modeling methods consisting of a teaching process that uses modelling with four phases. Modelling in physics is also considered in relation to inductivism and with experimental methods (Phạm, 2007).

VM: In mathematics didactics, the mathematical modelling competency is considered as one of the crucial competencies (Bui \& Chu, 2014). Bui and Chu (2014) propose some real life topics for the high school mathematical contest in modeling, which can help students develop modelling capacities. Ho (2018) uses the model of Blum \& Leiss (2005) to describe the process to solve realistic problems. The result of her questionnaire for grade 10 students shows that students have difficulties in mathematizing "real situation" to build a beneficial mathematical model, and in interpreting "mathematical solution" to "realistic solutions" for realistic problems. Thinh (2014) proposes methods of using models (which is called the method of symbolization) to teach analysis concepts efficiently. Tran et al. (2014) and Pham et al. (2018b) introduce methods of using mathematical software in teaching to create models such as graphs, figures, patterns or simulate objects, real world scenarios. This software-based modelling method can help to motivate students, diagnose their mathematical conceptions, visualize the problem situations, and overcome algebraic barriers (Tran et al., 2014; Pham et al., 2018b).

Now, if physics didactics has expertise on the subject of "models" and mathematics didactics has many years of research experience in modeling, an exchange of scientific knowledge on these themes seems obvious and profitable for both sides. The opportunities and challenges of bringing together mathematical modelling and modeling in physics lessons are shown by Neumann et al. (2011).

\section{Concept Formation}

GP \& GM: The terms are central elements of mathematics expertise and mathematics teaching. In mathematics education research, the learning of terms is generally understood as a constructive process, in which students develop an increasingly precise understanding of a term (Vollrath, 1984). A distinction is made between different types of conceptualization, including exemplary conceptualization, conceptualization through abstraction, specification from a generic term, and conceptualization based on actions (Weigand, 2015).

The supposedly greatest difference in the formation of concepts in mathematics and physics seems to be in the fact that concepts in mathematics are deductive determinations and in physics they are inductively obtained by classifying and systematizing empirical observations. This view is also supported by numerous older physics didactic works (e.g. Klinger, 1989). More recent studies discuss critically the purely inductive character of physical concepts (cf. Krause, 2017c). Although, terms in physics are stimulated by empirical phenomena, their epistemological character is more related to terms in mathematics: they are creations of the mind that are built into the deductively ordered mental building of science.

In mathematics didactics, abduction is discussed in connection with the topic of "concept formation" (Meyer \& Voigt, 2008 or also Söhling, 2015). For example, the didactic theory of concept learning is described and empirically researched on the basis of abduction (Meyer, 2012). 
VP: Nguyễn et al. (2002) and Đỗ (2012) introduce the concept of knowledge and concepts of natural cognitive methods. Each of these concepts is further divided into sub-concepts - corresponding to the steps to form them in physics teaching. Pham (2007) provides a model for formation the concept. This concept consists of field theory and real object field, and is accompanied by a concept formation process in teaching with four recommended stages.

VM: In mathematics didactics, it is important that we should form steadily a system of concepts for students because concepts are the fundamental basis of the mathematical knowledge. Nguyen (2017) mentions to three processes to approach a concept which are: the deductive process, the inductive process and the constructive process. He also shows advantages and limitations of each process. Some other research mentions specific methods to help students in concept formation, such as software-based modelling method (Pham et al., 2018b; Tran et al., 2014), using symbolized method (Thinh, 2014), construct learning tasks (Phan, 2015), applying constructivism theory (Bui, 2017) or using intuiting approach (Vo, 2018).

Abduction is also discussed in physics didactic research (cf. McComas, 2002), but it would be interesting to discuss it against the background of epistemological parallels to mathematics.

\section{Problem-solving}

Problem-solving is a fundamental competence of mathematics teaching and a classical field of research in mathematics education research. A lot of different conditions influence the problem-solving process, including cognitions (domain knowledge and heuristics), metacognition (knowledge about mathematical thinking, control processes) and the basic attitude. Mathematics education research examines, in particular, the course of problemsolving processes and the possibilities of acquiring problem-solving competence (Heinrich et al., 2015). Important representatives are Pólya (1949) and Schoenfeld (1985).

GP: In physics didactics, attempts are made to work out general heurisms as well as physics-specific solutions to problems. Among others, the knowledge-centered problem solving according to Friege (2001, Friege and Lind 2006) or the importance of basic physical principles in solving physical problems (Krause, 2013) should be mentioned.

GM: On the one hand, the many years of experience in mathematics didactics for problem-solving can provide profitable insights into physical problem-solving processes and competencies. On the other hand, applicationoriented problem-solving processes, in particular, can be examined more closely in teaching mathematics by physics education research.

VP: A problem solving model consisting of three phases and problem-solving strategies are recommended by Nguyễn et al. (2002). The theory of problem-solving teaching method under the consideration of psychological and natural science cognitions methods is introduced in detail by Pham (2007). The study of comparisons with project based learning is introduced by Trần (2010). Problem-based learning (PBL) is mentioned by Đỗ (2012). Recent outstanding research contributions include comparisons with the Lamap teaching perspective (Nguyễn \& Đỗ, 2016), problem solving in integrated teaching (Nguyễn, 2016) and introduction of students' problem solving competence (Đỗ et al., 2019; Phạm et al., 2018).

VM: In mathematics education, Nguyen (2017) mentions two popular ways to create a problematic situation and solve problems. He uses Pólya's idea to propose four steps to solve a problem: understanding the problem, find a solution, present the solution, and looking back to the problem (Nguyen, 2017). Researchers also discuss some other methods to help students in the problem-solving process such as closed-open approach (Tran, 2018), software-based modelling methods (Nguyen, 2018; Tran et al., 2014), intuiting approach (Vo, 2018), or method of building learning situations in mathematics to develop competencies of solving problems in real-world contexts (Pham et al., 2018a).

\section{Arguing and Proving}

GP: In physics lessons, argumentation and proving are implicitly relevant in the competency areas of communication and evaluation. Reasoning plays a central role in physics (Jiménez-Aleixandre, 2007). In physics didactic research, this is usually located at the interface between theoretical hypothesis and experimental data or observations with the question of when and how empirics and theory reinforce or correct each other. Empirical studies also deal with the argumentation ability of students of physics (e.g. Böttcher \& Meisert, 2011).

GM: In the curricular guidelines for mathematics teaching, argumentation and proving are usually presented as explicit process-related competences, since mathematics is regarded as the proving science. This is reflected in the mathematics didactic research on this topic (e.g. Hanna \& de Villiers, 2012).

VP: The analysis of arguing and proving types accompanying with a corresponding solution to encourage students to implement is presented by Nguyễn and Nguyễn (2001) and Nguyễn et al. (2002). The role of arguing and proving in teaching physics is introduced by Phạm (2001). Đỗ (2006) provides the scientific basis of arguing 
and proving, and applications in physics teaching. Trần (2016) analyzes a type of arguing and proving related to analogical reasoning in the history of physics.

VM: According to Nguyen (2017), to develop abilities to understand, present and perform proofs, it is necessary to train logical thinking, exact language capacity, prediction, imagination capacity, and also intellectual activities. Bui (2011) discusses how to teach students to argue and prove when they learn some specific mathematical knowledge. Dao \& Tran (2010) mention two types of arguments in students' cognitive activities and emphasized the important role of arguing in the problem solving process.

From the authors' point of view, the comparison of mathematical and physical work on the subject of argumentation and evidence is very fruitful, since it allows discussion of similarities and differences in the concept of truth. This opens a valuable reflection of the respective subject. Closely related to this, is also the comparative discussion on beliefs about mathematics and physics (Section "Beliefs about mathematics and physics"), which can be conducted more specifically on the subject of argumentation and proofs than if the comparison of different views is conducted only on a meta-level.

\section{Experimentation}

GP: In physics, an experiment is the observation and measurement of physical processes and objects under defined and controlled conditions in order to acquire knowledge. It is regarded as the fundamental justification instance in the scientific theory-building process. At school, the experiment has also many other functions besides the qualitative and quantitative verification of theories, e.g. the visualization of physical phenomena, the arousing of interest and the learning of scientific work. The didactic research deals among other things, with the functional aspects, the correct use and development of new innovative experiments for teaching (Girwidz, 2015a).

GM: In recent years, mathematics didactics has also become increasingly intertwined with experimentation. Mathematics is generally regarded as a deductive science, but some of the ways in which new knowledge is created are experimental. In contrast to physical science, however, only formal proof represents a final instance of justification. Thus, the function of the experiment in mathematics teaching is limited primarily to the generation and preliminary testing of hypotheses (Philipp, 2013).

VP: Nguyen and Nguyễn (2001) analyze the leading role of experiments in experimental methods, which play a decisive role in the discovery of knowledge of the natural world, and introduce a teaching method simulating experimental methods including five stages. Pham (2001), Nguyen et al. (2002) and Pham (2007) classify the types of experiments and recommend corresponding ways of teaching physics. Out of the important role, the designing, setting up and conducting of experiments are both considered as research topics (Mai \& Ngô, 2016) and are also considered as subjects to be learned by students (Nguyễn \& Trần, 2018).

VM: Nguyen (2017) emphasizes the role of experimentation in the process of forming and developing mathematical knowledge. He concludes that not only deduction but also predictions and experimentation should be included in teaching mathematics to achieve the comprehensive educational goal (Nguyen, 2017). Tran et al. (2014) use a software to do some experiments. Therefore, the students can predict the result and approach the mathematical concept.

The exchange about the role of experimentation in the respective discipline can provide important insights into the development of knowledge of the subjects. In particular, mathematics teaching can profit from the rich research results of physics didactics for experimenting.

\section{CONCLUSION}

The intention of the authors is to use this article to promote cooperation between mathematics and physics didactics in the fields of research and teaching and to identify possible research topics for cooperation between the two disciplines. The listed topics are considered here as examples, as a common basis on a content foundation. The results of the explication of potential interdisciplinary fields of work only reveal different points of contact for possible joint teaching and research projects between mathematics and physics didactics. Thus, related topics could be identified, a more detailed analysis of them could not be realized within this contribution but seems to be worthwhile. Therefore, these points of contact may be seen, for example, as suggestions for formulating interdisciplinary research questions, or as a starting point for discussing the curricular content of interdisciplinary courses. However, the qualitative method itself presented here can also serve as a model for analyses of the identification of related topics between other subject didactics in the STEM field, between subject didactics and their related disciplines or beyond.

The following research desiderata should be addressed on the basis of the research results of this article: 
- The explication described in "Comparison with the Vietnamese Literature" of contents that are relevant for both mathematics and physics didactics should be consolidated by separate publications by experts from both disciplines.

- The synergies of educational research of both subjects should be implemented in the corresponding teacher training programs. These team-teaching interventions should be designed and evaluated accordingly.

- The effect of such collaborations on the professional growth of the involved persons (teachers, teacher educators and scientists) needs to be investigated. The development of professional growth is a main goal of teaching and highly relevant in current research.

\section{ACKNOWLEDGEMENT}

The present analyses were carried out within the framework of the Inter TeTra project. The project is funded by the German Academic Exchange Service (DAAD) with funds from the German Federal Ministry for Economic Cooperation and Development (BMZ).

\section{REFERENCES}

Baker, C. K., \& Galanti, T. M. (2017). Integrating STEM in elementary classrooms using model-eliciting activities: responsive professional development for mathematics coaches and teachers. International Journal of STEM Education, 4(1), 1-15. https:/ / doi.org/10.1186/s40594-017-0066-3

Bauersfeld, H. (1983). Subjektive Erfahrungsbereiche als Grundlage einer Interaktions-theorie des Mathematiklehrens und -lernens. In H. Bauersfeld, H. Bussmann, \& G. Krummheuer (Eds.), Lernen und Lehren von Mathematik. Analysen zu Unterrichtshandeln II (pp. 1-56). Köln: Aulis.

Blum, W., \& Leiß, D. (2005). Modellieren im Unterricht mit der Tanken-Aufgabe. Der Mathematikunterricht, 25(1), $18-21$.

Böttcher, F., \& Meisert, A. (2011). Argumentation in Science Education: A Model-based Framework. Sci \& Educ, 20 (2), 103-140. https:// doi.org/10.1007/s11191-010-9304-5

Brandenburger, M., Mikelskis-Seifert, S., \& Labudde, P. (2014). Problemlösen in der Mechanik: eine Untersuchung mit Studierenden. Phy-DidB - Didaktik der Physik, Beitrag DD 13.05.

Bröll, L., \& Friedrich, J. (2012). Zur Qualifikation der Lehrkräfte für den NWA-Unterricht - eine Bestandsaufnahme in Baden-Württemberg. Der mathematische und naturwissenschaftliche Unterricht, 65(3), 180-186.

Brown, R. E., \& Bogiages, C. A. (2017). Professional Development Through STEM Integration: How Early Career Math and Science Teachers Respond to Experiencing Integrated STEM Tasks. International Journal of Science and Mathematics Education, 59(5), 389. https:/ / doi.org/10.1007/s10763-017-9863-x

Bruder, R., Linneweber-Lammerskitten, H., \& Reibold, J. (2015). Individualisieren und differenzieren. In R. Bruder, L. Hefendehl-Hebecker, B. Schmidt-Thieme, \& H.-G. Weigand (Eds.), Handbuch der Mathematikdidaktik (pp. 513-538). Berlin, Wiesbaden: Springer Spektrum. https:/ / doi.org/10.1007/978-3-642-35119-8_19

Büchter, A., Scheibke, N., \& Wilzek, W. (2017). Zur Problematik des Übergangs von der Schule in die Hochschule - Zielsetzungen, Eingangsvoraussetzungen und Wirksamkeit von Vorkursen Mathematik. In U. Kortenkamp, \& A. Kuzle (Eds.), Beiträge zum Mathematikunterricht 2017 (pp. 151-154). Münster: WTM.

Bui, V. N. (2011). Giáo trình Phương pháp dạy học nhũng nội dung cụ thể môn Toán. Hanoi: The HNUE Publishing House.

Bui, V. N. (2017). Vận dụng lí luận vào thực tiễn dạy học môn Toán ở trường phổ thông. Hanoi: The HNUE Publishing House.

Bui, V. N. (2018). Some contents integrating mathematics and physics in high school. Proceeding of the international conference in mathematics education: An integrated approach in mathematics education and teacher training.

Bui, V. N., \& Chu, C. T. (2014). High School Mathematical Contest in Modeling. Proceeding of the national conference of research on mathematics education in the orientation of developing learners' competencies for the period 2014-2020.

Carrejo, D. J., \& Marshall, J. (2007). What is mathematical modelling? Exploring prospective teachers use of experiments to connect mathematics to the study of motion. Mathematics Education Research Journal, (19), 4576. https:// doi.org/10.1007/BF03217449

Caviola, H. (2012). Wie Fächer miteinander ins Gespräch kommen: Modelle der Fächervernetzung und ihre Lernziele. In H. Caviola, et al. (Eds.), TriOS: Nr. 2/2012. Interdisziplinarität (5-36). Münster: LIT-Verlag. 
Communist Party of Vietnam (2013). Resolution on "Fundamental and comprehensive innovation in education, serving industrialization and modernization in a socialist-oriented market economy during international integration" ratified in the 8th session.

Cormas, P. C. (2017). Preservice Teachers' Reconciliation on an Epistemological Issue in an Integrated Mathematics/ Science Methods Course. International Journal of Science and Mathematics Education, 15, 14631483. https:// doi.org/10.1007/s10763-016-9755-5

Dao, T., \& Nguyen, C. T. (2015). Các năng lực cốt lõi của giáo viên Toán phổ thông đáp ứng yêu cầu đổi mới chương trình, sách giáo khoa môn Toán sau năm 2015. Proceeding of the conference of developing professional competencies for Vietnamese school mathematics teachers.

Dao, T., \& Tran, T. (2010). Tổ chức hoạt động nhận thức trong dạy học môn Toán ở trường Trung học phổ thông. Hanoi: The HNUE Publishing House.

Đào, V. P. (2003). Lịch sư vật lí học 2nd Edition. Hanoi, Vietnam: Vietnam Education Publishing House.

Defila, R., \& Di Giulio, A. (2002). “Interdisziplinarität” in der wissenschaftlichen Diskussion und Konsequenzen für die Lehrerbildung. In A. Wellensiek (Eds.). Interdisziplinäres Lehren und Lernen in der Lehrerbildung. Perspektiven für innovative Ausbildungskonzepte (S. 17-29). Weinheim, Basel: Beltz.

Dilling, F., Holten, K., \& Krause, E. (2019). Explikation möglicher inhaltlicher Forschungsgegenstände für eine wissenschaftskollaboration der Mathematik- und Physikdidaktik - Eine vergleichende Inhaltsanalyse aktueller deutschsprachiger Handbücher und Tagungsbände. Mathematica Didactica, 42, 1-18.

Đỗ, H. T. (2006). Lô gic học trong dạy học Vật lí. Hanoi. Vietnam: University of Education Publishing House.

Đỗ, H. T. (2012). Các kiểu tổ chức dạy học hiện đại trong dạy học vật li ở trường phổ thông 2nd Edition. Hanoi, Vietnam: University of Education Publishing House.

Đỗ, H. T. (2014). Lamap một phương pháp dạy học hiện đại - Cơ sở lí luận và việc vận dụng trong dạy học 2 nd Editon. Hanoi, Vietnam: Vietnam National University Press.

Đỗ, H. T., Nguyễn, V. B., Trần, K. N., Trần, T. N., Trần, T. T. T., ... Nguyễn, V. B. H. (2016). Dạy học tích hợp phát triển năng lực học sinh - khoa học tự nhiên. Hanoi, Vietnam: Vietnam National University Press.

Đỗ, H. T., Nguyễn, V. B., Tưởng, D. H., Dương, X. Q., \& Trần, B. T. (2019). Dạy học phát triển năng lực môn vật lí trung học phổ thông. Hanoi, Vietnam: University of Education Publishing House.

Doig, B., Williams, J., Swanson, D., Borromeo Ferri, R., \& Drake, P. (2019). Interdisciplinary Mathematics Education. Cham: Springer International Publishing. https:/ / doi.org/10.1007/978-3-030-11066-6

Duit, R. (2015). Alltagsvorstellungen und Physik lernen. In E. Kircher, R. Girwidz, \& P. Häußler (Eds.), Physikdidaktik. Theorie und Praxis (pp. 657-680). Berlin, Heidelberg: Springer. https://doi.org/10.1007/9783-642-41745-0_22

English, L. D. (2017). Advancing Elementary and Middle School STEM Education. International Journal of Science and Mathematics Education, 15, 5-24. https:/ / doi.org/10.1007/s10763-017-9802-x

Euler, M., Schüttler, T., \& Hausamann, D. (2015). Schülerlabore: Lernen durch Forschen und Entwickeln. In E. Kircher, R. Girwidz, \& P. Häußler (Eds.). Physikdidaktik. Theorie und Praxis (pp. 759-782). Berlin, Heidelberg: Springer. https://doi.org/10.1007/978-3-642-41745-0_26

Fischler, H. (2015). Aus- und Fortbildung von Physiklehrkräften. In E. Kircher, R. Girwidz, \& P. Häußler (Eds.). Physikdidaktik. Theorie und Praxis (pp. 681-704). Berlin, Heidelberg: Springer. https://doi.org/10.1007/9783-642-41745-0_23

Friege, G. (2001). Wissen und Problemlösen. Eine empirische Untersuchung des wissenszentrierten Problemlösens im Gebiet der Elektrizitätslehre auf der Grundlage des Experten-Novizen-Vergleich. Berlin: Logos-Verlag.

Friege, G., \& Lind, G. (2006). Types and Qualities of Knowledge and their Relations to Problem Solving in Physics. International Journal of Science and Mathematics Education, 4(3), 437-465. https:/ / doi.org/10.1007/s10763-0059013-8

Fullan, M. (2007). The new meaning of educational change. New York: Routledge.

Galili, I. (2018). Physics and Mathematics as Interwoven Disciplines in Science Education. Science E Education, 27, 7-37. https://doi.org/10.1007/s11191-018-9958-y

Girwidz, R. (2015a). Medien im Physikunterricht. In E. Kircher, R. Girwidz, \& P. Häußler (Eds.). Physikdidaktik. Theorie und Praxis (pp. 193-246). Berlin, Heidelberg: Springer. https:/ / doi.org/10.1007/978-3-642-41745-0_6

Girwidz, R. (2015b). Neue Medien und Multimedia. In E. Kircher, R. Girwidz, \& P. Häußler (Eds.). Physikdidaktik. Theorie und Praxis (pp. 401-428). Berlin, Heidelberg: Springer. https://doi.org/10.1007/978-3-642-417450_12 
Greefrath, G., Oldenburg, R., Siller, H. -S., Ulm, V., \& Weigand, H. -G. (2016): Aspects and „Grundvorstellungen” of the Concepts of Derivative and Integral. Journal für Mathematik-Didaktik, 37(1), 99-129. https:/ / doi.org/10.1007/s13138-016-0100-x

Grigutsch, S., Raatz, U., \& Törner, G. (1998). Einstellungen gegenüber Mathematik bei Mathematiklehrern. Journal für Mathematik-Didaktik, 19, 3-45. https:/ / doi.org/10.1007/BF03338859

Hà, T. T. L. (2016). Những vấn đề về khả năng diễn đạt trong dạy học vật lí của người học. Proceeding of Vietnam national conference for physics teaching, 17-21.

Hanna, G., \& de Villiers, M. (2012, Eds.). Proof and Proving in Mathematics Education. The 19th ICMI Study. Dordrecht et al.: Springer. https:/ / doi.org/10.1007/978-94-007-2129-6

Hattie, J., \& Beywl, W. (2013). Lernen sichtbar machen. Baltmannsweiler: Schneider-Verlag.

Hayden, M., \& Thiep, L. Q. (2015). A 2020 Vision for Higher Education in Vietnam. International Higher Education. Advance online publication. https://doi.org/10.6017/ihe.2006.44.7913

Heering, P. (2013). Der Elektrische Salon: Physikgeschichte. Phy-DidB - Didaktik der Physik, Beitrag DD 17.47.

Heinrich, F., Bruder, R., \& Bauer, C. (2015). Problemlösen lernen. In R. Bruder, L. Hefendehl-Hebeker, B. SchmidtThieme, \& H.-G. Weigand (Eds.). Handbuch der Mathematikdidaktik (pp. 279-301). Berlin, Heidelberg: Springer. https://doi.org/10.1007/978-3-642-35119-8_10

Heuling, L. (2015). Heterogene Lernvoraussetzungen in naturwissenschaftlichen Bildungsprozessen. Phy-DidB Didaktik der Physik, Beitrag DD 02.20.

Ho, T. M. P (2018). A Study on Difficulties of Grade 10 Students in Integrating Procedural and Conceptual Knowledge on Quadratic Equations to Solve Realistic Problems. Proceeding of the international conference in mathematics education: An integrated approach in mathematics education and teacher training.

Hoang, C. K., \& Phan, T. T. (2015). Phát triển năng lực dạy học theo yêu cầu đổi mới giáo dục cho sinh viên sư phạm Toán thông qua các môn khoa học cơ bản. Proceeding of the conference of developing professional competencies for Vietnamese school mathematics teachers.

Höttecke, D., \& Rieß, F. (2007). Rekonstruktion der Vorstellungen von Physikstudierenden über die Natur der Naturwissenschaften - eine explorative Studie. Physik und Didaktik in Schule und Hochschule, PhyDid A, 6(1), $1-14$.

Jahnke, H. N., \& Ufer, S. (2015). Argumentieren und Beweisen. In R. Bruder, L. Hefendehl-Hebecker, B. SchmidtThieme, \& H.-G. Weigand (Eds.). Handbuch der Mathematikdidaktik (pp. 331-357). Berlin, Wiesbaden: Springer Spektrum. https://doi.org/10.1007/978-3-642-35119-8_12

Jiménez-Aleixandre, M. P. (2007). Designing Argumentation Learning Environments. In S. Erduran, \& M. P. Jiménez-Aleixandre (Eds.), Argumentation in Science Education (pp. 91-117). Dordrecht: Springer Netherlands. https://doi.org/10.1007/978-1-4020-6670-2_5

Jörissen, S., \& Schmidt-Thieme, B. (2015). Darstellen und Kommunizieren. In R. Bruder, L. Hefendehl-Hebeker, B. Schmidt-Thieme, \& H.-G. Weigand (Eds.). Handbuch der Mathematikdidaktik (pp. 385-408). Berlin, Heidelberg: Springer. https://doi.org/10.1007/978-3-642-35119-8_14

Jürgensen, F. (2012). Das integrierte Fach Naturwissenschaften und seine Beliebtheit bei Lehrern und Schülern. In E. Rossa (Eds.), Chemie-Didaktik. Praxishandbuch für die Sekundarstufe I und II (pp. 197-230). Berlin: Cornelsen Scriptor.

Kaiser, G., Blum, W., Borromeo Ferri, R. \& Greefrath, G. (2015). Anwendungen und Modellieren. In R. Bruder, L. Hefendehl-Hebeker, B. Schmidt-Thieme, \& H.-G. Weigand (Eds.). Handbuch der Mathematikdidaktik (pp. 357383). Berlin, Heidelberg: Springer. https:/ / doi.org/10.1007/978-3-642-35119-8_13

Kircher, E., Girwidz, R., \& Häußler, P. (2015). Physikdidaktik. Theorie und Praxis. Berlin, Heidelberg: Springer.

Klinger, W. (1989). Bildung physikalischer Begriffe und ihre Vermittlung im Unterricht. In W. B. Schneider (Eds.). Wege in der Physikdidaktik. Band 1. Sammlung aktueller Beiträge aus der physikdidaktischen Forschung (pp. 19-29). Erlangen: Palm \& Enke. https:/ / doi.org/10.1007/978-3-642-41745-0

KMK (2004). Standards für die Lehrerbildung: Bildungswissenschaften. Beschluss vom 16.12.2003 i.d.F. vom 12.06.2014. Kultusministerkonferenz 16.12.2004.

Kraus, S., Krause, E., \& Dilling, F. (2018). Inter-TeTra - A German-Vietnamese project combining physics and mathematics didactics. Vietnam Journal of Education, 2(5), 1-8.

Krause, E. (2013). Das Erhaltungsprinzip in der Physik und seine Anwendung im Physikunterricht. Dissertation an der Universität Siegen.

Krause, E. (2015). Nutzen von fächerverbindender Didaktik am Beispiel von subjektiven Lernvoraussetzungen im Mathematik- und Physikunterricht. Beiträge zum Mathematikunterricht, 48, 492-495. 
Krause, E. (2016). Die Übergangsproblematik von der Schule zur Hochschule im Fach Physik aus lerntheoretischer Sicht. PhyDid B - Didaktik der Physik - Beiträge zur DPG-Frühjahrstagung, Beitrag DD 08.04.

Krause, E. (2017a): Physikdidaktik in der Mathematiklehrerbildung? Anregungen zur fachdidaktischverbindenden Lehrerbildung. Beiträge zum Mathematikunterricht, 50.

Krause, E. (2017b). Mathematikdidaktik in der Physiklehrerbildung? Projekte zur fachdidaktisch-verbindenden Lehrerbildung. PhyDid B - Didaktik der Physik - Beiträge zur DPG-Frühjahrstagung, Beitrag DD 5.4.

Krause, E. (2017c): Einsteins EJASE-Modell als Ausgangspunkt physikdidaktischer Forschungsfragen Anregungen aus einem Modell zur Natur der Naturwissenschaft. Physik und Didaktik in Schule und Hochschule (PhyDid A), 16(1), 57-66.

Krause, E. (2018). Epistemological Parallels between Mathematics in School and Physics. Vietnam Journal of Education, 2(5), 14-20.

Krause, E., Bien, N. V., Chat, T. N., Chi, N. P., Dilling, F., Geppert, J., ... Tho, C. C. (2019). Inter TeTra Interdisciplinary Teacher Training with Mathematics and Physics. Description of a Project Partnership between Siegen (Germany) and Hanoi National University of Education (Vietnam). Proceedings of the Eleventh Congress of the European Society for Research in Mathematics Education.

Krauthausen, G. (2018). Einführung in die Mathematikdidaktik - Grundschule. Berlin, Heidelberg: Springer. https://doi.org/10.1007/978-3-662-54692-5

Labudde, P. (2014). Fächerübergreifender naturwissenschaftlicher Unterricht - Mythen, Definitionen, Fakten. Zeitschrift für Didaktik der Naturwissenschaften, 20(1), 11-19. https:/ / doi.org/10.1007/s40573-014-0001-9

Labudde, P. (Hrsg.) (2008). Naturwissenschaften vernetzen - Horizonte erweitern: Fächerübergreifender Unterricht konkret. Seelze-Velber: Klett/Kallmeyer.

Lamprecht, X. (2017). Erfassung der konnotativen Überzeugungen von Lehramtsstudierenden zur Mathematik als Wissenschaft und als Schulfach. In U. Kortenkamp, \& A. Kuzle (Eds.), Beiträge zum Mathematikunterricht 2017 (pp. 593-596). Münster: WTM.

Lê, C. T., \& Lê, T. T. (2004). Phân tích chương trình vật lí phổ thông. Hue, Vietnam: University of Hue Publishing House.

Le, V. H. (2015). Chuẩn bị của sinh viên sư phạm nhằm phát triển năng lực sử dụng ngôn ngữ Toán học của học sinh trong dạy học môn Toán ở trường phổ thông. Proceeding of the conference of developing professional competencies for Vietnamese school mathematics teachers.

Lengnink, K., \& Roth, J. (2017). Lernprozesse in Lehr-Lern-Laboren Mathematik. In Kortenkamp, U. \& Kuzle, A. (Hrsg.). Beiträge zum Mathematikunterricht 2017 (pp. 1267-1268). Münster: WTM.

Leuders, T. (2015). Aufgaben in Forschung und Praxis. In R. Bruder, L. Hefendehl-Hebeker, B. Schmidt-Thieme, \& H.-G. Weigand (Eds.). Handbuch der Mathematikdidaktik (pp. 435-460). Berlin, Heidelberg: Springer. https://doi.org/10.1007/978-3-642-35119-8_16

Leuders, T. (Eds.) (2003). Mathematik Didaktik. Praxishandbuch für die Sekundarstufe I und II. Berlin: Cornelsen.

Loos, A., \& Ziegler, M, (2015). Gesellschaftliche Bedeutung der Mathematik. In R. Bruder, L. Hefendehl-Hebecker, B. Schmidt-Thieme, \& H.-G. Weigand (Eds.). Handbuch der Mathematikdidaktik (pp. 3-18). Berlin, Wiesbaden: Springer Spektrum.

Mai, H. P., \& Ngô, M. N. (2016). Thiết kế bộ cảm biến kết nối không dây với máy vi. Proceeding of Vietnam national conference for physics teaching, 68-75.

Mayring, P. (2000). Qualitative Inhaltsanalyse. Weinheim. Basel: Beltz.

McComas, W. F. (Ed.). (2002). Science \& Technology Education Library. The Nature of Science in Science Education. Dordrecht: Kluwer Academic Publishers. https:/ / doi.org/10.1007/0-306-47215-5

Meyer, M. (2012). Vom Satz zum Begriff. Berlin, Heidelberg: Springer Spektrum.

Meyer, M., \& Voigt, J. (2008). Entdecken mit latenter Beweisidee - Analyse von Schulbuchseiten. Journal für Mathematik-Didaktik. https:/ / doi.org/10.1007/BF03339057

Michelsen, C. (1998). Expanding Context and Domain: A Cross-Curricular Activity in Mathematics and Physics. ZDM, 30, 100-106. https:/ / doi.org/10.1007/BF02653149

Mikelskis, H. (Ed.) (2006). Physik Didaktik. Praxishandbuch für die Sekundarstufe I und II. Berlin: Cornelsen.

Mikelskis-Seifert, S. (Ed.) (2011). Modelle. Naturwissenschaften im Unterricht Physik 122.

Mikelskis-Seifert, S., \& Kasper, L. (2011). Modellieren in der Physik, im Alltag und im Unterricht. Hintergründe und unterrichtliche Orientierung zum Thema Modelle. Naturwissenschaften im Unterricht. Physik, 122, 4-12. 
Moegling, K. (2010). Kompetenzaufbau im fächerübergreifenden Unterricht: Förderung vernetzten Denkens und komplexen Handelns. Didaktische Grundlagen, Modelle und Unterrichtsbeispiele für die Sekundarstufen I und II. Immenhausen bei Kassel: Prolog-Verl.

MOET (Vietnam Ministry of Education and Training) (2018). School Educational Curriculum: The General Curriculum. Retrieved on 13 May 2019 from https:/ / data.moet.gov.vn/index.php/s/LETzPhj5sGGnDii\#pdfviewer

MOET (Vietnam Ministry of Education and Training) (2018). School Educational Curriculum: The Mathematics Curriculum,

Müller, A. (2015). Astronomie im Unterricht. In Kircher, E., Girwidz, R. \& Häußler, P. (Eds.). Physikdidaktik. Theorie und Praxis (pp. 529-552). Berlin, Heidelberg: Springer. https://doi.org/10.1007/978-3-642-41745-0_17

Neumann, I., Heinze, A., Ufer, S., \& Neumann, K. (2011). Modellieren aus mathematischer und physikalischer Perspektive. Beiträge zum Mathematikunterricht, 603-607.

Nguyen V. B. (2015). Developing and teaching multidisciplinary topics in science integrated. Journal of Science of HNUE, 60(2), 61-66. https:/ / doi.org/10.18173/2354-1075.2015-0031

Nguyen V. B., \& Thanh H. N. (2014). Integrierter Naturwissenschaftenunterricht. Educational Equipment Magazine, 110.

Nguyen, A. Q. (2018). Integrated Teaching of Parametric Equations of Straight Line to Tenth-Graders in High School With Geogebra. Proceeding of the international conference in mathematics education: An integrated approach in mathematics education and teacher training.

Nguyen, B. K. (2017). Phương pháp dạy học môn Toán. Hanoi: The HNUE Publishing House.

Nguyen, B. K., Dinh, N. C., Nguyen, M. C., Vu, D. T., \& Nguyen, V. T (1994). Phương pháp dạy học môn Toán. Phần 2: Dạy học những nội dung cơ bản. Hanọi: The Vietnamese Educational Publishing House.

Nguyễn, Đ. T., \& Nguyễn, N. H. (2001). Tổ chức hoạt động nhận thức cho học sinh trong dạy học vật lí ở trường phổ thông 2nd Editon. Hanoi, Vietnam: Vietnam National University Press.

Nguyễn, Đ. T., Nguyễn, N. H., \& Phạm, X. Q. (2002). Phương pháp dạy học vật lí ở trường phổ thông. Hanoi, Vietnam: University of Education Publishing House.

Nguyễn, M. H. (2016). Dạy học tích hợp chủ đề “Năng lượng gió và sử dụng năng lượng gió" nhằm phát triển năng lực giải quyết vấn đề của học sinh trung học cơ sở. Proceeding of Vietnam national conference for physics teaching, 100-107.

Nguyen, P. C (2016). Vì sao nên dạy học Toán theo hướng tích hợp? Educational Science Journal, 2016(1), 13-15.

Nguyen, P. C., \& Nguyen, T. H. P. (2019). Teaching mathematics at the high school level in an integrated way through interdisciplinary projects. HNUE project in education.

Nguyen, P. C., Ngo, T. T. Q., \& Nguyen, T. H. P. (2018). Teaching mathematics at the high school level in an integrated way. Vietnam Journal of Education, 2(5), 21-27.

Nguyen, T. N. (2013). Selling western dreams: Australian transnational education in Vietnam and the formation of students' identities. https:/ / doi.org/10.4225/03/58869696EC94A

Nguyễn, T. T., \& Đỗ, H. T. (2016) Dạy học Vật lí theo quan điểm của Lamap nhằm phát triển năng lực giải quyết vấn đề cho học sinh. Proceeding of Vietnam national conference for physics teaching, 226-234.

Nguyễn, V. B., \& Trần, N. C. (2018). Đề xuất mô hình hoạt động của trung tâm STEM tại trường sư phạm. Proceeding of Vietnam national conference for physics teaching, 07-12.

Nguyen, V. B., Tuong, D. H., Tran, M. D., Nguyen, V. H., Chu, C. T., Nguyen, A. T., ... Doan, V. T. (2019). Giáo dục STEM trong nhà trường phổ thông. Hanoi: The Vietnamese Educational Publishing House.

Oh, P. S., \& Oh, S. J. (2011). What Teachers of Science Need to Know about Models: An overview. International Journal of Science Education, 33(8), 1109-1130. https:/ / doi.org/10.1080/09500693.2010.502191

Opitz, E. M., \& Nührenbörger, M. (2015). Diagnostik und Leistungsbeurteilung. In R. Bruder, L. HefendehlHebecker, B. Schmidt-Thieme, \& H.-G. Weigand (Eds.). Handbuch der Mathematikdidaktik (pp. 491-512). Berlin, Wiesbaden: Springer Spektrum. https:/ / doi.org/10.1007/978-3-642-35119-8_18

Pehkonen, E., \& Pietilä, A. (2004). On relationships between beliefs and knowledge in mathematics education. European Research in Mathematics Education III: Proceedings of the Third Conference of the European Society for Research in Mathematics Education. Retrieved from http:/ / www.dm.unipi.it/ didattica/CERME3/proceedings/Groups/TG2/TG2_pehkonen_cerme3.pdf

Phạm, H. T. (2001). Lí luận dạy học vật lí ở trường trung học. Hanoi, Vietnam: Vietnam Education Publishing House.

Phạm, H. T. (2007). Dạy học vật lí ở trường phổ thông theo định hướng phát triển hoạt động học tích cực, tự chủ, sáng tạo và tư duy khoa học. Hanoi, Vietnam: University of Education Publishing House. 
Pham, S. N, Hoa, A. T., Ha, X. T., \& Mai, X. V. (2015). Một số định hướng trong dạy học phân hóa môn Toán ở trường Trung học phổ thông nhằm phát triển năng lực học sinh. Proceeding of the conference of developing professional competencies for Vietnamese school mathematics teachers.

Pham, S. N., Do, T. D, \& Le, H. T. (2018a). Orientations for Building Learning Situations in Mathematics to Link the Competency of Mathematical Problem Solving to Real Life. Proceeding of the international conference in mathematics education: An integrated approach in mathematics education and teacher training.

Pham, S. N., Le, H. T., \& Do, T. D. (2018b). Some Practical Directions in Using Mathematical Software in the New Mathematics Curriculum for High Schools in Vietnam. Proceeding of the international conference in mathematics education: An integrated approach in mathematics education and teacher training.

Pham, X. C. (2015). Phát triển năng lực đánh giá kết quả học tập cho sinh viên ngành sư phạm Toán thông qua dạy học các học phần nghiệp vụ sư phạm. Proceeding of the conference of developing professional competencies for Vietnamese school mathematics teachers.

Phạm, X. Q., \& Lê, V. T. S. (2018). Phát triển năng lực giải quyết vấn đề của học sinh thông qua tổ chức hoạt động ngoại khóa về các ứng dụng kĩ thuật của vật lí thuộc chương chất khí - Vật lí lớp 10. Proceeding of Vietnam national conference for physics teaching, 98-103.

Phan, T. P. T. (2015). The competence of instructing students to self-study concepts in teaching mathematics at secondary schools. Proceeding of the conference of developing professional competencies for Vietnamese school mathematics teachers.

Philipp, K. (2013). Experimentelles Denken. Theoretische und empirische Konkretisierung einer mathematischen Kompetenz. Wiesbaden: Springer. https://doi.org/10.1007/978-3-658-01120-8

Philipp, K. (2015). Kinder experimentieren mit Zahlen - Eine mathematische Tätigkeit unter der Lupe. In F. Caluori, H. Linneweber-Lammerskitten, \& C. Streit (Hrsg.) Beiträge zum Mathematikunterricht 2015 (34-41). Münster: WTM.

Polya, G. (1949). Schule des Denkens. Vom Lösen mathematischer Probleme. Tübingen: Francke.

Rehm, M., Bünder, W., Haas, T., Buck, P., Labudde, P., Brovelli, D., ... Svoboda, G. (2008). Legitimationen und Fundamente eines integrierten Unterrichtsfachs Science. Zeitschrift für Didaktik der Naturwissenschaften, 14, 99-123.

Reiss, K., \& Hammer, C. (2013). Grundlagen der Mathematikdidaktik. Basel: Birkhäuder. https:/ / doi.org/10.1007/9783-0346-0647-9

Rincke, K., \& Leisen, J. (2015). Sprache im Physikunterricht. In E. Kircher, R. Girwidz, \& P. Häußler (Eds.). Physikdidaktik. Theorie und Praxis (pp. 636-655). Berlin, Heidelberg: Springer. https://doi.org/10.1007/9783-642-41745-0_21

Ríordáin, M. N., Johnston, J., \& Walshe, G. (2016). Making mathematics and science integration happen: key aspects of practice. International Journal of Mathematical Education in Science and Technology, 47(2), 233-255. https:/ / doi.org/10.1080/0020739X.2015.1078001

Roetger, R., \& Wodzinski, R. (2017). Wie fachspezifisch ist das Naturwissenschaftsverständnis? PhyDid B - Didaktik der Physik - Beiträge zur DPG-Frühjahrstagung, Beitrag DD 09.02.

Rott, B., Groß Ophoff, J., \& Leuders, T. (2017). Erfassung der konnotativen Überzeugungen von Lehramtsstudierenden zur Mathematik als Wissenschaft und als Schulfach. In U. Kortenkamp, \& A. Kuzle (Eds.) Beiträge zum Mathematikunterricht 2017 (1101-1104). Münster: WTM.

Rott, B., Leuders, T., \& Stahl, E. (2015). Assessment of Mathematical Competencies and Epistemic Cognition of PreService Teachers. Zeitschrift für Psychologie, 223(1), 39-46. https:/ / doi.org/10.1027/2151-2604/a000198

Schoenfeld, A. H. (1985). Mathematical problem-solving. Orlando: Academic.

Schoenfeld, A. H. (1998). Toward a Theory of Teaching-in-Context. Issues in Education, 4(1), 1-94. https:/ / doi.org/10.1016/S1080-9724(99)80076-7

Schorcht, S. (2017). Von Anamaya bis John Neper - Mathematikgeschichte in Schulbüchern der Grundschule. In U. Kortenkamp, \& A. Kuzle (Eds.), Beiträge zum Mathematikunterricht 2017 (pp. 869-872). Münster: WTM.

Sevinc, S., \& Lesh, R. (2018). Training mathematics teachers for realistic math problems: a case of modeling-based teacher education courses. ZDM, 50(1-2), 301-314. https:/ / doi.org/10.1007/s11858-017-0898-9

Söhling, A. C. (2015). Problemlösen - Mittels Irrtümern zu strukturellen Erkenntnissen. Beiträge zum Mathematikunterricht 2015.

Struve, H. (2015). Zur geschichtlichen Entwicklung der Mathematikdidaktik als wissenschaftlicher Disziplin. In R. Bruder, L. Hefendehl-Hebecker, B. Schmidt-Thieme, \& H.-G. Weigand (Eds.). Handbuch der 
Mathematikdidaktik (pp. 539-566). Berlin, Wiesbaden: Springer Spektrum. https://doi.org/10.1007/978-3642-35119-8_20

Thinh, T. B. T. (2014). Symbolized method in teaching analysis concepts in the Vietnamese high schools. Proceeding of the national conference of research on mathematics education in the orientation of developing learners' competencies for the period 2014-2020.

Tran, K. (2015). Về mục tiêu môn Toán trong trường phổ thông Việt nam. Proceeding of the conference of developing professional competencies for Vietnamese school mathematics teachers.

Tran, L. T., \& Marginson, S. (2018b). Internationalisation of Vietnamese Higher Education: Possibilities, Challenges and Implications. In L. T. Tran, \& S. Marginson (Eds.), Higher Education Dynamics. Internationalisation in Vietnamese Higher Education (pp. 253-257). Cham: Springer International Publishing. https:/ / doi.org/10.1007/978-3-319-78492-2_14

Tran, L. T., \& Marginson, S. (Eds.). (2018a). Higher Education Dynamics. Internationalisation in Vietnamese Higher Education. Cham: Springer International Publishing. https:/ / doi.org/10.1007/978-3-319-78492-2

Trần, N. C. (2013). Die Bedeutung von Wasserkraftwerken für die zukünftige Energieversorgung Vietnams Vorstellung eines Konzepts für den Schulunterricht. PhyDid B, 2013(1), 1-7.

Trần, N. C. (2016). Tương tự trong nghiên cứu và trong dạy học vật lí. Proceeding of Vietnam national conference for physics teaching, 57-67.

Trần, N. C., \& Kraus, S. (2017). Eingestrahlte Sonnenenergie auf eine Dachschräge. Von den theoretischen Grundlagen zum Modellexperiment. Der mathematischen und naturwissenschaftlichen Unterrichts, 2017(1), 3235.

Trần, N. C., \& Krause, E. (2017). Herleitung der Sonnenscheinformel und Bestimmung der eingestrahlten Sonnenenergie durch Koordinatentransformationen als fächerverbindender Lehrinhalt. Der Mathematikunterricht, 2017(5), 50-56.

Tran, T., \& Nguyen, N.G.(2015). Sử dụng sách điện tử hỗ trợ việc giải bài tập hình học phẳng theo hướng phân nhánh. Proceeding of the conference of developing professional competencies for Vietnamese school mathematics teachers.

Tran, T., Phan, A. H., \& Nguyen, T. H. (2014). Ứng dụng công nghệ thông tin trong dạy học Toán theo hướng phát triển năng lực của học sinh phổ thông. Proceeding of the national conference of research on mathematics education in the orientation of developing learners' competencies for the period 2014-2020.

Tran, V. (2018). Bringing Mathematics Education into the Global Orbit to Develop Thinking, Logic and Creativity in Solving Realistic Problems with Closed-Open Approach. Proceeding of the international conference in mathematics education: An integrated approach in mathematics education and teacher training.

Trần, V. T. (2010). Rèn luyện tư duy phê phán và tư duy sáng tạo của học sinh trong dạy học vật lí thông qua dạy học dự án. Proceeding of Vietnam national conference for physics teaching, 133-138.

Treacy, P., \& O'Donoghue, J. (2014). Authentic Integration: a model for integrating mathematics and science in the classroom. International Journal of Mathematical Education in Science and Technology, 45(5), 703-718. https:// doi.org/10.1080/0020739X.2013.868543

Ufer, S., Heinze, A., \& Lipowsky, F. (2015). Unterrichtsmethoden und Instruktionsstrategien. In R. Bruder, L. Hefendehl-Hebecker, B. Schmidt-Thieme, \& H.-G. Weigand (Eds.). Handbuch der Mathematikdidaktik (pp. 411434). Berlin, Wiesbaden: Springer Spektrum. https://doi.org/10.1007/978-3-642-35119-8_15

Vo, X. M. (2018). Developing Students'Mathematical Intuitive Competence Based on Learning Meaningful Knowledge in Mathematics Education. Proceeding of the international conference in mathematics education: An integrated approach in mathematics education and teacher training.

Vollrath, H.-J. (1984). Methodik des Begriffslehrens. Stuttgart: Klett.

Vom Hofe, R. (1992). Grundvorstellungen mathematischer Inhalte als didaktisches Modell. Journal für MathematikDidaktik, 13(4), 345-364. https:/ / doi.org/10.1007/BF03338785

Vom Hofe, R., Lotz, J., \& Salle, A. (2015). Analysis: Leitidee Zuordnung und Veränderung. In R. Bruder, L. Hefendehl-Hebecker, B. Schmidt-Thieme, \& H.-G. Weigand (Eds.). Handbuch der Mathematikdidaktik (pp. 149184). Berlin, Wiesbaden: Springer Spektrum. https:/ / doi.org/10.1007/978-3-642-35119-8_6

Vu, T. B. (2015). Năng lực biểu diễn Toán học của học sinh Trung học cơ sở và những lưu ý trong đào tạo sinh viên sư phạm Toán. Proceeding of the conference of developing professional competencies for Vietnamese school mathematics teachers. 
Weigand, H.-G. (2015). Begriffsbildung. In R. Bruder, L. Hefendehl-Hebeker, B. Schmidt-Thieme, \& H.-G. Weigand (Eds.). Handbuch der Mathematikdidaktik (pp. 255-278). Berlin, Heidelberg: Springer. https:/ / doi.org/10.1007/978-3-642-35119-8_9

Wellensiek, A. (Hrsg.) (2002). Interdisziplinäres Lehren und Lernen in der Lehrerbildung: Perspektiven für innovative Ausbildungskonzepte.Weinheim, Basel: Beltz.

Whitney, K., Reid, L., \& Streitwieser, B. (2018). Vietnam and Higher Education Internationalization: The Promise of Community Colleges. In R. Latiner Raby, \& E. J. Valeau (Eds.), Springer International Handbooks of Education. Handbook of Comparative Studies on Community Colleges and Global Counterparts (Vol. 2013, pp. 541-553). Cham: Springer International Publishing. https:/ / doi.org/10.1007/978-3-319-50911-2_19

Wiesner, H., Schecker, H., \& Hopf, M. (2011). Physikdidaktik kompakt. Hallbergmoos: Aulis.

Witzke, I., \& Spies, S. (2016). Domain-Specific Beliefs of School Calculus. Journal für Mathematik-Didaktik, 37(1), 131161. https:// doi.org/10.1007/s13138-016-0106-4

Zech, F. (2002). Grundkurs Mathematikdidaktik. Weinheim, Basel: Beltz. 


\section{APPENDIX}

Table 4. Categories and examples of structuring analysis

\begin{tabular}{|c|c|c|c|}
\hline \multirow{2}{*}{$\begin{array}{c}\text { Main } \\
\text { Category }\end{array}$} & \multirow{2}{*}{ Category } & \multicolumn{2}{|c|}{ Paradigmatic Examples } \\
\hline & & Germany & Vietnam \\
\hline \multirow{8}{*}{$\begin{array}{l}\text { Mathematics } \\
\text { and physics } \\
\text { education } \\
\text { research as } \\
\text { scientific } \\
\text { disciplines }\end{array}$} & \multirow{2}{*}{ C1.1: relevance of mathematics and physics } & Loos \& Ziegler (2015) & Nguyễn (2002) \\
\hline & & Kircher (2015) & Bùi (2018) \\
\hline & \multirow{2}{*}{$\begin{array}{l}\text { C1.2: Mathematics and physics education } \\
\text { research as scientific disciplines }\end{array}$} & Struve (2015) & Nguyễn (2002) \\
\hline & & Kircher (2015) & Nguyễn (2017) \\
\hline & \multirow{2}{*}{ C1.3: Beliefs about mathematics and physics } & Rott et al. (2017) & Nguyễn (2001) \\
\hline & & Roetger \& Wodzinski (2017) & Nguyễn (2017) \\
\hline & \multirow{2}{*}{$\begin{array}{l}\text { C1.4: History of mathematics and physics (in } \\
\text { class) }\end{array}$} & Schorcht (2017) & Đào (2003) \\
\hline & & Heering (2013) & Nguyễn et.al (1994) \\
\hline \multirow{5}{*}{$\begin{array}{l}\text { Educational } \\
\text { research } \\
\text { theories }\end{array}$} & \multirow{2}{*}{ C2.1: Didactical principles } & Reiss \& Hammer (2013) & Nguyễn (2002) \\
\hline & & Kircher (2015) & Nguyễn (2017) \\
\hline & \multirow{2}{*}{ C2.2: Preconceptions } & Lamprecht (2017) & Đỗ (2014) \\
\hline & & Wiesner et al. (2011) & Nguyễn (2017) \\
\hline & C2.3: Subject-matter didactics & $\begin{array}{l}\text { Vom Hofe et al. (2015) } \\
\text { Müller (2015) }\end{array}$ & $\begin{array}{c}\text { Nguyễn (2002) Nguyễn } \\
\text { (2017) }\end{array}$ \\
\hline \multirow{14}{*}{$\begin{array}{c}\text { Goals and } \\
\text { Competences } \\
\text { in } \\
\text { Mathematics } \\
\text { and Physics } \\
\text { Teaching }\end{array}$} & \multirow{2}{*}{ C3.1: Goals and competences } & Reiss \& Hammer (2013) & Đỗ (2019) \\
\hline & & Kircher (2015) & Trần (2015) \\
\hline & \multirow{2}{*}{ C3.2: Model / Modeling / Applications } & Kaiser at al. (2015) & Nguyễn (2001) \\
\hline & & Kircher (2015) & Vũ (2015) \\
\hline & \multirow{2}{*}{ C3.3: Concept development } & Weigand (2015) & Nguyễn (2002) \\
\hline & & Wiesner et al. (2011) & Thịnh (2014) \\
\hline & \multirow{2}{*}{ C3.4: Problem solving } & Heinrich et al. (2015) & Nguyễn (2001) \\
\hline & & Brandenburger et al. (2014) & Nguyễn (2017) \\
\hline & \multirow{2}{*}{ C3.5: Arguing and proofing } & Jahnke \& Ufer (2015) & Đỗ (2006) \\
\hline & & Ludwig \& Priemer (2018) & Nguyễn (2017) \\
\hline & \multirow{2}{*}{ C3.6: Experimenting } & Philipp (2015) & Nguyễn (2002) \\
\hline & & Wiesner et al. (2011) & Trần et.al (2014) \\
\hline & \multirow{2}{*}{ C3.7: Communication and language } & Jörissen \& Schmidt-Thieme (2015) & Đỗ (2014) \\
\hline & & Rincke \& Leisen (2015) & Lê (2015) \\
\hline \multirow{6}{*}{$\begin{array}{l}\text { Teacher } \\
\text { Training }\end{array}$} & \multirow{2}{*}{$\begin{array}{c}\text { C4.1: Teacher training / teacher } \\
\text { professionalization / teacher competence }\end{array}$} & Krauthausen (2018) & Phạm (2016) \\
\hline & & Fischler (2015) & Dao \& Nguyen (2015) \\
\hline & \multirow{2}{*}{$\begin{array}{l}\text { C4.2: Science labs / Teaching and learning } \\
\text { laboratories }\end{array}$} & Lengnink \& Roth (2017) & Nguyễn (2018) \\
\hline & & Euler et al. (2015) & NV \\
\hline & C4.3: Transition from school to university / & Büchter et al. (2017) & NV \\
\hline & start of studies & Krause (2016) & Hoàng \& Phan (2015) \\
\hline & K5.1: Planning, analysis and organisation of & Leuders (2003) & Nguyễn (2002) \\
\hline & lessons & Kircher (2015) & Nguyễn (2017) \\
\hline & & Ufer et al. (2015) & Đỗ (2012) \\
\hline Teaching & C5.2: teachıng methods & Kircher (2015) & Nguyễn (2017) \\
\hline practice and & & Opitz \& Nührenbörger (2015) & Đỗ (2019) \\
\hline pedagogical & C5.3: Performance assessment and diagnosis & Wiesner et al. (2011) & Phạm (2015) \\
\hline topics & & Leuders(2003) & Nguyễn (2002) \\
\hline & C5.4: Media & Girwidz (2015b) & Trần \& Nguyễn (2015) \\
\hline & C5.5: Differentiation / Heterogeneity / & Bruder et al. (2015) & Đỗ (2012) \\
\hline & Inclusion & Heuling (2017) & Phạm et al. (2015) \\
\hline & & Reiss \& Hammer (2013) & $\mathrm{NV}$ \\
\hline & C6: Tasks & Wiesner et al. (2011) & NV \\
\hline C7: Interdi & sciplinary collaboration of mathematics and & Holten \& Witzke (2017) & NV \\
\hline & physics education researchers & Krause $(2017 b)$ & NV \\
\hline
\end{tabular}

\section{http://www.ejmste.com}

